\title{
THE INFLUENCE OF PRODUCTION, EXPORTS PRICE, EXCHANGE RATE, GRATEKS- 2/GERNAS POLICY, AND EXPORT DUTIES ON COCOA COMMODITY EXPORTS IN SOUTH SULAWESI, INDONESIA
}

\author{
Hasbiullah* \\ University of Islam Negeri Alauddin, Makassar, Indonesia \\ Pudjihardjo M., Sasongko, Noor I. \\ University of Brawijaya, Indonesia \\ *E-mail: hasbiullahjabbar@gmail.com
}

\begin{abstract}
The objective of this research is to analyze the influence of production, exports price, exchange rate, Grateks-2/Gernas policy, and export duties policy on cocoa exports in South Sulawesi using data from 1986 until 2015 and employing an analysis technique of Error Correlation Model (ECM). This study has already found that cocoa production, exports price, long-terms and short-terms exchange rate give a positive influence, while the production rate gives a significant influence on cocoa exports in South Sulawesi. It means that during the analysis time period, the production rate still shows a significant influence on cocoa bean export. However, if regarded from the data development in 2010, the exports development of cocoa bean actually showed a steady decrease since 2011 . On the other hand, the production increased at that time, if further analyzed with long data so can be projected that the relationship of production with cocoa bean exports will be totally different along with the growth of domestic industry. Later on, Grateks-2/Gernas policy of cocoa shows a different result. This variable has a positive and negative relationship between long-term and short-term period respectively, and both of them have a significant influence or not enough evidence. The exports duties have a negative and significant influence. This result can be seen both in the long-term and short-term period meaning that the government policy of PMK Number 067/PMK.011/2010 of applying export duties work well to switch exports from cocoa bean to produced cocoa, this matter can be seen from the development of produced cocoa production, applied capacity development and investment in produced cocoa production drastically increasing every year.
\end{abstract}

\section{KEY WORDS}

Production, exports rate, Grateks-2/Gernas, exchange rate, export duties, cocoa export.

South Sulawesi is one of the provinces in Indonesia that produce the cocoa commodity and the largest producer among all cocoa producing provinces in Indonesia.

Following the declining number of cocoa exports so this research is directed to see the variables determining the intended increase or decline. The following several studies will show variables which influence that exports, among others, are conducted by Abologba, Onyekwere, Agbonkpolor, and Umar (2010) about Determining factor of agriculture Exports with selected commodity, i.e. Cocoa and Rubber in Nigeria. They try to observe factors that influence agricultural exports with special reference, i.e. cocoa and rubber by using secondary data with regression analysis tool of Ordinary Least Squares (OLS). OLS finding shows that rubber exports are significantly influenced by local rubber production, producer price, exchange rate, domestic consumption, and interest rate. While the world rubber price is not significant. For cocoa, OLS shows that cocoa output, domestic consumption, and rainfall significantly influence cocoa exports. While the producer price, global cocoa price, exchange rate, and interest rate are not significant. This study is supported by Grafoute Amoro and Yao Shen's (2013) finding who try to conduct a similar study with a different place, which was in Gading Beach. They study about Determining Factor of Agricultural 
Exports, especially Cocoa and Rubber at the Gading beach by employing secondary data. Analysis technique used was ordinary Least Squares (OLS) Regression to analyze relevant data. OLS finding discloses that the rubber exports are significantly influenced by rubber production, producer price, value, consumption and interest rate. For cocoa, OLS shows that cocoa output, domestic consumption, and rainfall significantly influence cocoa exports.

This is in accordance with the study conducted by Okoruwa (2003) observing export determinant of traditional agriculture in Nigeria, with one of the commodities observed is cocoa and the data collected for 37 years by contemplating Cointegration and Correlation model (ECM) analysis. The research result proves that agricultural exports to the United States, Netherland, English, German, and France, are influenced by domestic output, population growth, quantity supplied by competitor countries, production index of competitor countries, and time trend. However, domestic output and population growth rate are the most significant factors that influence agriculture exports in importing countries.

It is totally different from the study conducted by Kannan (2013) trying to test the factor determining natural rubber exports in India. OLS finding admits that natural rubber exports influenced by stock, world price, domestic price, world population have a significant influence on natural rubber exports, while the production is not, as with the study conducted by Khalifah (2016) finding that the production of sesame export and production relationship have a significant influence on cotton exports. This is extremely different from what Abologba, Onyekwere, Agbonkpolor, and Umar (2010), Grafoute Amoro and Yao Shen (2013) found that exactly discover significance rate at rainfall variable.

Furthermore, a discussion about the exchange rate, in line with Abolagba's (2010) finding above, a study carried out by Mesike (2010) also found a negative relationship between rubber export and exchange rate. This means that the lower exchange rate during the domestic currency devaluation causes an export increase. Domestic consumption has a negative relationship with rubber export. This means that the decrease in domestic consumption will cause an export supply increase and vice versa.

\section{MATERIALS AND METHODS OF RESEARCH}

Following the problem of this research, which is by analyzing the determinant factor of South Sulawesi's cocoa commodity exports, so this research design employees a statistical quantitative approach with time series data analysis. The intended model of time series data analysis is Error Correction Model (ECM).

This approach is used because time series data is frequently non-stationary that causes spurious regression. Spurious regression is a situation by which the regression result shows a significant coefficient statistically and a high value of the coefficient of determination but the relationship among variables within the model is not correlated to each other. The proper model for non-stationer time series data is Error Correlation Model (Widarjono: 2013).

Time series data analysis method is used to test whether Production Rate, Exports price, Exchange Rate, Grateks-2/Gernas Policy, and Export duties have a significant influence or not on cocoa commodity exports in South Sulawesi. While the model of ECM-EG is employed to overcome non-stationer time series data problem and spurious regression problem.

A general formula of time series data used is as follows:

$$
Y_{t}=\alpha+\beta X_{t}+\varepsilon_{t} ; t=1,2, \ldots T
$$

Where: $\mathrm{T}=$ The number of time series data.

That formula can be elaborated in a clearer form as follows:

$$
\mathrm{qxc}=\beta_{0}+\beta_{1} \mathrm{qpc} c_{t}+\beta_{2} \mathrm{xpc}_{t}+\beta_{3} \mathrm{er}_{t}+\beta_{4} g 2 g c_{t}+\beta_{5} x d c_{t}+e
$$

Where: $q x c=$ the dependent variable represents the quantitiy exported from cocoa bean in kilograms. 
The independent variables are: $q p c=$ quantities produced of cocoa bean in kilograms; $\mathrm{xpc}=$ export pricesof cocoa beans(US\$) are stated in FOB prices; er = exchange rate (Rp/US\$); g2gc = policy of Grateks-2/Gernas (Dummy Variable). (there is policy=1, no policy=0).

Grateks-2/gernas is the abbrevation of South Sulawesi Government program that encourage farmer to orient their products for export to gain higher selling price/national movements: $x d c=$ export duty policy of $\operatorname{cocoa}(D u m m y$ Variable).(there is policy $=1$, no policy $=0) ; \beta_{0}=$ constants; $\beta=$ coefficientof regression; $\mathrm{e}=$ error term.

While Engel-Granger's Error Correction Model (ECM) is as follows:

$$
\Delta \mathrm{qxc}=\beta_{0}+\beta_{1} \Delta \mathrm{qpc}_{\mathrm{t}}+\beta_{2} \Delta \mathrm{xpc}_{\mathrm{t}}+\beta_{3} \Delta \mathrm{er}_{\mathrm{t}}+\beta_{4} \mathrm{~g}_{2} \mathrm{gc}_{t}+\beta_{5} \mathrm{xdc}_{t}+E C_{t}+e
$$

Where: $E C_{t}=$ Error Correction(residual lag 1).

\section{RESULTS AND DISCUSSION}

An important thing from the usage of regression and time series data is the problem of data stationary. Time series data is frequently not stationary that causes spurious regression result. A correct model for non-stationary time series data is employeeng error correction model.

A number of testing conducted in an analysis stage among others; unit root test, cointegration test, regression test by using Error Correlation Model (ECM) and classical test. That testing stage in a data analysis was elaborated from the following classical assumption test.

Stationary Detection: Unit Root Test. Data stationary testing is conducted to achieve a stationary condition at the observed variable, both independent and dependent variable. That testing uses an Augmented Dickey-Fuller and Philip-Pheron testing where the ECM requirement is the non-stationary at level 0 . Therefore, it has to be differentiated at the degree of 1 . The hypotheses of this research are:

- The observed variable has non-stationary data;

- The observed variable has a stationary data.

The observed variable has a non-stationary data and accepts hypothesis $\mathrm{HO}$, which is if the significance value of ADF or PP test at the particular level is bigger than alpha $5 \%$. If this condition happens so it needs to conduct retesting by increasing integrity degree to the maximum to get stationary data condition, which is if the significance value is smaller than alpha $5 \%$.

Table 1 - The Result of Data Stationary Test

\begin{tabular}{|c|c|c|c|c|c|}
\hline \multirow{2}{*}{ Level } & \multirow{2}{*}{ Variable } & \multicolumn{2}{|c|}{ ADF } & \multicolumn{2}{|r|}{ PP } \\
\hline & & Sig & Description & Sig & Description \\
\hline \multirow{4}{*}{ Level 0} & Ekspor (qxc) & 0.3944 & Not-Stationary & 0.4047 & Not-Stationary \\
\hline & Production (qpc) & 0.3620 & Not-Stationary & 0.3459 & Not-Stationary \\
\hline & Exports Price (xpc) & 0.8668 & Non-Stationary & 0.9819 & Not-Stationary \\
\hline & Exchange Rate (er) & 0.9213 & Non-Stationary & 0.9133 & Not-Stationary \\
\hline \multirow{4}{*}{ Level 1} & Ekspor (qxc) & 0.0000 & Stationary & 0.0000 & Stationary \\
\hline & Production (qpc) & 0.0112 & Stationary & 0.0112 & Stationary \\
\hline & Exports Price (xpc) & 0.0111 & Stationary & 0.0111 & Stationary \\
\hline & Exchange Rate (er) & 0.0038 & Stationary & 0.0038 & Stationary \\
\hline
\end{tabular}

Source: Analysis result, processed data.

Based on table 1, it can be known that the significance value of ADF or PP at the level 0 of all variables $>0.05$ that can be concluded that the data used is not stationary. The test result at level 1 (diff 1 ) shows that all variables have been stationary at the level of 1difference and ECM requirement has been fulfilled.

Cointegration Test Result (Engle-Granger). Engle-granger test is conducted to determine whether there is or not cointegration relationship between independent variable 
and dependent variable through residual test from the obtained equation. This test is conducted using the Engle-Granger test. Economically, the cointegrated variable is a condition where there is a long-term relationship among that variable. The result of the cointegration test is as follows:

Table 2 - Cointegration Test Result

RESID01 has a unit root

Constant

0 (Automatic based on SIC, MAXLAG=7)

t-Statistic

\begin{tabular}{llll}
\hline \hline Augmented Dickey-Fuller test statistic & & -5.908025 & 0.0000 \\
\hline Test critical values: & $1 \%$ level & -3.679322 & \\
& $5 \%$ level & -2.967767 & \\
& $10 \%$ level & -2.622989 & \\
\hline \hline
\end{tabular}

*MacKinnon (1996) one-sided p-values.

Cointegration test at residual shows that probability value obtained is 0.0000 by which it is smaller than alpha $5 \%$. Therefore, it can be stated that there is cointegration between the independent and dependent variable. This indicates that the variable is long-run equilibrium.

Model Estimation Result of Long-term Cocoa Commodity Exports Determinant Variable. The following is the regression result to get an empirical model with forming variable of cocoa commodity exports $=\mathrm{f}$ (production, exports price, exchange rate, grateks2/gernas policy, exports duties can be seen after the following table explanation:

Table 3 - Parameter Estimation Result of Long-term Model

\begin{tabular}{|c|c|c|c|c|}
\hline Variable & Coefficient & Error & t-Statistic & Prob \\
\hline C & 31530633 & 20118796 & 1.567223 & 0.1302 \\
\hline Product (qpc) & 0.717692 & 0.139443 & 5.146849 & $0.0000^{* * *}$ \\
\hline Export Prices (xpc) & 2656037 & 15120904 & 0.175653 & 0.8620 \\
\hline Exchange Rate (er) & 473.5314 & 2941.172 & 0.161001 & 0.8734 \\
\hline Grateks-2/Gernas (g2gc) & 10522228 & 17563752 & 0.599088 & 0.5547 \\
\hline Export Duty (xdc) & -94781664 & 24880203 & -3.809521 & $0.0009^{* * *}$ \\
\hline R-squared & 0.845202 & Mean dependent var & $1.21 \mathrm{E}+08$ \\
\hline Adjusted R-squared & 0.812952 & S.D. dependent var & 67142492 \\
\hline S.E. of Regression & 29038473 & Akaike info criterion & 37.38300 \\
\hline Sum squared resid & $2.02 \mathrm{E}+16$ & Schwarz criterion & 37.66324 \\
\hline Log likelihood & -554.7450 & Hannan-Quinn criter. & 37.47265 \\
\hline F-Statistic & 26.20811 & Durbin-Watson stat & 2.146863 \\
\hline Prob (F-statistic) & 0.000000 &
\end{tabular}

Source: Data Processed. *) $\left.\left.\alpha=10 \%,{ }^{* *}\right) \alpha=5 \%,{ }^{* * *}\right) \alpha=1 \%$.

Partial Test (t-test):

- Production (qpc) has a probability value of 0.0000 smaller than the alpha error rate $=$ $5 \%$ so that individually has had enough evidence that production (qpc) has a significant influence on Exports Volume (qxc);

- Exports price $(\mathrm{xpc})$ has Probability value by 0.8620 bigger than the alpha error rate of $5 \%$ so that individually said to not have enough evidence to state that the Exports price (xpc) has a significant influence on Exports Volume (qxc);

- Exchange rate (er) has a probability value of 0.8734 bigger than the alpha error rate of $5 \%$ so that individually stated that it has no strong evidence to state that the Exchange Rate (er) has a significant influence on Exports Volume (qxc);

- Grateks-2/Gernas (g2gc) has a Prob value of 0.5547 bigger than the alpha error rate of $5 \%$ so that individually stated that having no strong evidence to state that Grateks2/Gernas (g2gc) has a significant influence on Exports Volume (qxc); 
- Exports duties (xdc) have a probability value of 0.0009 smaller than the alpha error rate of $5 \%$ so that individually stated that it has already had strong evidence to state that Exports duties have a significant influence on Export Volume (qxc).

Simultaneous Test (F-test). Because the probability value of 0.000 is bigger than the alpha error rate by $5 \%$ so that jointly the independent variable, i.e. Production (qpc), Exports Price (xpc), and Exports Duties (xdc) have a significant influence on Exports Volume Change (qxc).

The equation of the formed long-term model:

$$
q \times c_{t}=31530633+0.717692 q p c_{t}+2656037 x p c_{t}+473.5314 e_{t}+10522228 g 2 g c_{t}-94781664 x d c_{t}
$$

The value of $\left(\mathrm{R}^{2}\right)$ by 0.845202 or $84.52 \%$ means that the diversity Exports Volume (qxc) variable can be explained by independent variable, i.e. production (qpc), exports price (xpc), exchange rate (er), grateks-2/gernas (g2gc), and exports duties.

The equation above is a long-term equation model which shows that duties variable is the most dominant variable to influence long-term cocoa commodity exports. This can be proven from the coefficient size of export duties variable compared to another variable that influences coca commodity export.

Variable Model Estimation Result of Short-term Cocoa Commodity Determinant. The following is the regression result to get an empirical model of ECM with a determinant variable of coca commodity export $=f$ (production, exports price, exchange rate, grateks2/gernas policy, export duties) can be seen after the table explanation below:

Table 4 - Estimation Result of ECM Model Parameter

\begin{tabular}{|c|c|c|c|}
\hline Variable & Coefficient & t-Statistic & Prob \\
\hline $\mathrm{C}$ & 6966545 & 0.981205 & 0.3372 \\
\hline Product D(qpc) & 0.420756 & 2.520600 & $0.0195^{\star \star \star}$ \\
\hline Export Prices D(xpc) & 460505.2 & 0.038671 & 0.9695 \\
\hline Exchange Rate D(er) & 5207.257 & 1.380670 & 0.1812 \\
\hline Grateks-2/Gernas (g2gc) & -8312287 & -0.967481 & 0.3438 \\
\hline Export Duty (xdc) & -22390105 & -2.118955 & $0.0456^{\star *}$ \\
\hline RESID01(-1) & -0.917173 & -5.323597 & 0.0000 \\
\hline R-squared $\left(\mathrm{R}^{2}\right)$ & \multicolumn{3}{|l|}{0.6334} \\
\hline F-Statistic & \multicolumn{3}{|l|}{6.337361} \\
\hline Probability (F-statistic) & \multicolumn{3}{|l|}{0.000552} \\
\hline
\end{tabular}

Source: Data Processed *) $\left.\left.\alpha=10 \%,{ }^{* *}\right) \alpha=5 \%,{ }^{* *}\right) \alpha=1 \%$.

Partial Test (t-test):

- Production D (qpc) has a Probability value of 0.0195 smaller than the alpha error rate of $5 \%$ so that individually has strong evidence to state that production $D$ (qpc) has a significant influence on Export Volume (qxc);

- Export Price D (xpc) has a Probability value of 0.9695 bigger than the alpha error rate of $5 \%$ so that individually stated that it has no strong evidence to state that the export price $D(x p c)$ has a significant influence on Exports Volume (qxc);

- Exchange Rate D (er) has a probability value of 0.1812 bigger than the alpha error rate of $5 \%$ so that individually stated that it has no strong evidence to state that the exchange rate $\mathrm{D}$ (er) has a significant influence on Export Volume (qxc);

- Grateks-2/Gernas (g2gc) has a Probability value of 0.3438 bigger than the alpha error rate of $5 \%$ so that individually stated that it has no clear evidence to state that Grateks-2/Gernas (g2gc) has a significant influence on Export Volume (qxc);

- Export duties (xdc) has a Probability value of 0.0456 smaller than the alpha error rate of $5 \%$ so that individually stated that it has clear evidence to state that the export duties (xdc) have a significant influence on Export Volume (qxc);

- RESID01 (ECT-1) has a Probability value of 0.000 or smaller than the alpha error rate of $5 \%$ so that individually stated that ECT has a significant influence on Export Volume (qxc). 
Simultaneous Test (F-test). Because the probability value is 0.000 or smaller than the alpha error rate of $5 \%$ so that jointly independent variable, i.e. production $D$ (qpc), Export Prices D (xpc), Exchange Rate D (er), Grateks-2/gernas (g2gc), export duties (xdc) and $E C T_{t-1}$ have a significant influence on Change qxc.

The formed ECM equation:

$\Delta q \times c=6966545+0.420756 \Delta \mathrm{qpc}_{\mathrm{t}}+460505.2 \Delta \mathrm{xpc}_{\mathrm{t}}+5207.257 \Delta \mathrm{er}_{\mathrm{t}}-8312287 \mathrm{~g} 2 \mathrm{gc}_{\mathrm{t}}-22390105 \mathrm{xdc}_{\mathrm{t}}-$ $0.917173 \mathrm{ECT}_{\mathrm{t}-1}$

$\left(R^{2}\right)$ value of 0.6333 or $63.33 \%$ means that variable diversity qxc can be explained by independent variable, i.e. Production D (qpc), Export Price D (xpc), Exchange Rate (xdc), and $\mathrm{ECT}_{\mathrm{t}-1}$. The remaining of 36.67 is influenced by another variable not included in the model.

\section{CONCLUSION}

Following the problem, theory, hypotheses, analysis method, and finding about determinant factor of South Sulawesi's cocoa commodity export, this research give some conclusions below:

Analysis result shows that cocoa production, export price, exchange rate, both longterm, and short-term give a positive influence, but the one giving significant influence is the production level to South Sulawesi's cocoa export meaning that in a time period of production rate analysis still shows a significant influence on cocoa bean export, but if considering data development after 2010, export development of cocoa bean actually shows a steady decrease started in 2001 while the production increased in the same year, if furtherly analyzed with long data so it can be projected that the relationship of production and cocoa bean export will be contrary to the development of domestic industry.

Grateks-2/gernas policy of cocoa shows a different result. This variable has a positive and negative relationship for a long term and short term period respectively and both of them has no significant influence or enough evidence. This also proves that actually the program run by the government, referring to the production result, increases because in 2010 to 2011 cocoa production increase but actually showed a steady decrease of cocoa bean, if analyzed from the program of an increase in production so that the data from the discussion result gives information that the government program is successful, but there is a conflict with other policies in part of cocoa bean exports.

Export duties (Export tax) have a negative and significant influence. This can be seen from both long-term and short-term meaning that the government policy by applying export duties will be able to decrease South Sulawesi's cocoa bean export. In this case, the policy issued by the government, which is PMK Number 067/PMK.001/2010 works enough to switch export from cocoa bean to produced cocoa, this can be seen from cocoal production development and the development of applied capacity and investment in increasng cocoa production dratically increasee every year.

Finally, long-term equation generally gives us information that the variable of Production (qpc), Export price (xpc), Exchange Rate (er), Grateks-2/gernas (g2gc), and Export duties (xdc) simultaneously has a significant influence on Cocoa Export Volume (qxc). This can be seen from the probability value (F-statistics) by 0.000000 or smaller than the alpha rate of $0.05(5 \%)$, and short-term equation gives us information that the variable of production (qpc), Export Price (xpc), Exchnage Rate (er), Grateks-2/gernas (g2gc), and Export duties (xdc) simultaneously has a significant influence on cocoa Export Volume (qxc). This also can be seen from the probability value (F-statistic) by 0.000552 or smaller than the alpha rate of $0.05(5 \%)$. In addition, based on the speed of adjustment value, there is 91.72 percent of imbalance at the short-term influence of production (qpc), Export Price (xpc), Exchange Rate (er), Grateks-2/gernas (g2gc), and Export Duties (xdc) to the Cocoa Export Volume (qxc) corrected every period. 


\section{REFERENCES}

1. Abologba, E. O, Onyekwere, N.C, Agbonkpolor, B.N and Umar H.Y (2010). Determinants of Agriculltural Exports. Journal of human Ecology, 29(3):181 - 184

2. Amoro, G. \& Shen, Y. 2013. The Determinants of Agricultural Export: Cocoa and Rubber in Cote d'Ivoire, International Journal of Economics and Finance; Vol. 5, No. 1; 2013.

3. Arsyad, M. \& Yusuf, S. 2008. Assessing the Impact of Oil Prices and Interest Rate Policies: The Case of Indonesian Cocoa. Ryukoku Journal of Economic Studies, 48 (1): 65-92.

4. Kannan, M. 2013. The Determinants of Production and Export of Natural Rubberin India, OSR Journal of Economics and Finance (IOSR-JEF), Volume 1, Issue 5 (2013), PP 4145. www.iosrjournals.org.

5. Khalifah, E.A. 2016. Economics Of Non-Oil Exports Of Sudan. RJOAS, 10(58), October 2016.

6. Mesike, S. 2012. Impactt of Goverment agricultural Policies on Exports of Cocoa and Rubber in Nigeria. Rubber Research Institute of Nigeria, Benin City, Edo State, Nigeria. AGRICULTURA TROPICA ET SUBTROPICA, 45/4, 184-188, 2012.

7. 2010. Analysis of determinants of Rubber Export supply in Nlgeria. MSC thesis in Ibadan: Unversity of Ibadan, pp 94-98.

8. Okoruwa, V.O., Ogundare, G.O., \& Yusuf, S.A. 2003. Determinants of traditional agricultural exports in Nigeria: an application of cointegration and correction model. Quarterly Journal of International Agriculture 42 (2003), No. 4; DLG-Verlag Frankfurt/M.

9. Widarjono, A. 2013. Ekonometrika: Pengantar dan Aplikasinya. Yogyakarta: Penerbit UPP STIM YKPN. 